\title{
SECURITIZATION AND MILITARIZATION OF THE BORDER: SECURITY DILEMMA IN POST- 1998 ETHIOPIA AND ERITREA
}

MERESSA TSEHAYE CEBREWAHD

The post-1991 Ethiopia and Eritrea were hoped to become promising and exemplary states in Africa. But, after seven years of euphoria, national stability and security trapped both countries into a bloody conflict, and their relation is now in structural crisis: the 'no war, no peace' dilemma. Their security dilemmas are basically centered on the antagonistic foreign and national security as well as nation-building policies. The post-independence nation-building attempt to forge a militarized single national identity in Eritrea, under the motto of "one people, one heart" and the remaking of the age-old Ethiopian state based on ethnic federalism further deepen the nation-building dilemma. The post-1998 security dilemma between the two states is, therefore, the result of securing Eritrea's nation-building policies and the militarization of the Yika'alo-Warsay generation where Ethiopia has been made to be "a relevant enemy to its Singaporization vision" and Eritrea is subsequently viewed as a "relevant enemy to Ethiopia's renaissance vision and securitization of poverty". During the militarization of the borders, Badme still remains symbolically the hotbed of the 'no war, no peace' regime. This article, therefore, analyzes the post-2000 security dilemma between Ethiopia and Eritrea and the subsequent dynamics that have led to securing and/or militarizing their relations.

\section{Conceptual framework: security, securitization and militarization}

Security has been exclusively defined as a state's ability to survive and prosper in the self-help, anarchic international system (Wing, 2000). According to the traditional school of security, state's security threats were regarded external in their origin and militaristic in their nature. The instruments of defense were military capabilities and wars were considered to be fought outside the jurisdiction of the state (Rourke, 1993). In this regard, states were considered as the only referent object (i.e., unit of analysis) and provider of security. Non-state actors were neglected as marginal units (Buzan, 1991). Therefore, security was defined as a phenomenon of war: focusing on the threat, and the use and control of the military force (Walt, 1991).

The end of the Cold War, however, resulted in a major blow to the traditional (state-centric realists and territorialist) schools and led to the emergence of critical schools of security studies: "widening and deepening" (Hough, 2004: 4-6). The 
Widening schools called for horizontal inclusions threats (both military and nonmilitary) that could emerge both from outside and inside the state, and instigated by both state and non-state actors (Buzan, 1991). The Deepening schools called for the vertical actors' redefinition of referent objects for security to include non-state actors, mainly human beings, human security, migration, and minority self-determination rights, and so on, as units of analysis (Willians, 2004). According to the critical school (mainly the Deepening one), states are not only referents and the providers of security, but also could be a source of threats to their citizens.

The concept of securitization entered into the vocabulary of international relations after Ole Wæver outlined it in 1995. The Copenhagen school was also pioneering in mainstreaming the concept of securitization into the study of international relations. It conceptualized securitization as a process taking place beyond or outside "normal politics" (McDonald, 2008). It has been applied into the analyses of state foreign policy behaviors, transnational crime and war on terror, minority rights, and secessionist and irredentist armed struggles for independence. And indeed, since 2001, securitization includes human security, and immigrants and asylum seekers as threats to the sovereignty and identity of the nation-states in Europe (McDonald, 2008).

Moreover, securitization can be defined as the positioning through speech acts (usually by a political leader) of a particular issue as a "threat to survival", which in turn enables emergency measures and the suspension of normal politics while dealing with an existential threat. The main argument in securitization is that security is a speech act. It is about the labeling of a particular referent object, which is threatened in its existence, and thus, a securitizing actor claims a right to extraordinary measures to ensure the referent object's survival. Securitization moves beyond the sphere of normal politics into the realm of emergency politics (Taureck, 2006: 3).

According to Barry Buzan, as cited in Taureck (2006: 3), 'everything' should not be the subject of securitization as it requires emergency responses beyond normal politics to prevent the securitizing actor from annihilation. He further argues that in order to prevent 'everything' from a security issue, securitization should consist of three issues and steps: "identification of existential threats; emergency action; and effects on inter-unit relations by breaking free of rules." (Taureck, 2006: 3) Securitization is, therefore, all about giving prior attention (emergency status) to the referent object so that to prevent itself from existential threats.

Militarism and militarization that had traditionally been interchangeably used, on the other hand, were associated with aggressive foreign policy and backed up by an unwarranted and threatening military buildup, given the capacity to exercise the use of force in resolving conflicts between states. The critical proponents of militarization were realist schools that argued for building military power under the

The concept of securitization entered into the vocabulary of international relations after Ole Waver outlined it in 1995. 
principle of "realpolitik." The principle of realpolitik further holds that countries should practice balance of power politics to ensure their national security through "either building up your own strength, allying yourself with others or dividing your opponents" (Rourke, 1993). Hence, militarization should aim at "increasing power, keeping power, or demonstrating power." (Rourke, 1993)

According to Michael Klare (1978), militarization was a tendency of a nation's military apparatus (which includes the armed force, intelligence, and the bureaucratic agencies) to assume ever-increasing control over the lives and behaviors of citizens, for military goals (preparation for war, acquisition of weaponry, and the development of military industries), and military values (centralization of authority, discipline and conformity, combativeness and xenophobia). Furthermore, militarization is a process of change in the state and in the relationship between state and society. It is also about the process of politico-military and economic development dynamics of building a modern nation-state. Richard Tanter (1984) identified five dimensions of militarization including expanded military force structure; military predominance in politics; a preference for a coercive solution to political problems; cultural support for organized state violence; and a degree of offensively-oriented external military alignment, alliance, or war-fighting capacity.

Methodologically, this article analyzed the securitization and militarization dynamics of the post-1998 Ethiopia and Eritrea qualitatively and the resultant 'no war, no peace' stalemate regime. Finally, the paper has the following specific objectives; i.e., to critically examine the history of militarization and securitization of relations between Ethiopia and Eritrea; to analyze the post-war legal (the Algiers Agreement and the Hague border verdict) and diplomatic (UNSC sanctions against Eritrea) battles; the 'no war, no peace' regime, and indefinite regional security dilemma, which all "blurred" the prospect for normalization (even after the June 2018 rapprochement between president Isaias of Eritrea and prime minister Abiy Ahmed of Ethiopia) and aggravate the proliferation of fragile states in the Horn of Africa as a result.

\section{The pre-1998 trajectories of the security dilemma between Ethiopia and Eritrea}

There is no common agreement, as to the causes of the hostile relation between Ethiopia and Eritrea, though their relationship following independence, it was hoped that they would contribute to the stabilization of the conflict-prone region of the Horn and the leaders of the two countries were viewed as a "new breed of African statesmen" (Gebru, 2009: 344). According to Gebru (2006: 53), the border issue was not the pivotal cause of the conflict, but the real causes have been related to the nation-building aspirations and the nature of the states. He added that the conflict was "contention between a new state too zealous to solidify its statehood and an older one too jealous to protect its sovereignty." For Berhane (2006: 31), the conflict with Ethiopia was part of "Eritrea's war for national unity" through conducting wars and severing the ethnic ties with all its neighbors with the ultimate goal of reengineering a new Eritrean national identity, because all ethnic groups of Eritrea have trans-border ties. 


\subsection{A securitized development: The economic viability of development in Eritrea and Ethiopia}

According to Gebru Asrat (2006: 58), the former president of Tigray, the economic issues that had led to a confrontation between the two countries began to surface immediately after the end of the Eritrean liberation war. Following the referendum, the Eritrean leadership declared the development vision to make Eritrea "self-sufficient" and the "industrial powerhouse of the Horn", and ultimately to replicate Singapore in the region by the year of 2015 - 'Singaporization' (Solomon, 1998: 15). The actualization of this economic vision assumed "a large and untapped Ethiopian market, and cheap migrant labor from Ethiopian hinterland for Eritrean industrialization." (Gebru, 2006: 58) In 1991, the two countries agreed to use a "common currency until Eritrea issued its own currency, Assab and Massawa would be free ports for Ethiopia, and Ethiopia in return would run and maintain the Assab oil refinery." (Tekeste and Tronvoll, 2000: 35) And, in September 1993, both countries signed the "Asmara Pact" (Gebru, 2006: 58) that covered all fields of cooperation including a defense pact. In line with the stated agreement, Eritrea demanded that trade and investment should be open to resident and non-resident nationals of both countries without restriction and on equal treatment (Gebru, 2006: 58).

At the heart of the grand vision was that the Eritrean intellectuals and policymakers envisaged that Eritrea would remain the heartland of the Horn with its skilled human resources and the overvalued ports which were basically considered strong bargaining instruments against Ethiopia (Tekeste, 1997). The politics of Eritrean ports as part of the nation-building narratives remained part of the mainstream of the Ethiopia-Eritrea relations and became over-politicized mainly during the Dergue regime, for which "losing Eritrea would mean cutting Ethiopia's neck" (Tekeste, 1997: 174). This indeed remains as part of the post-independent Eritrean national narrative failing to take into account alternative ports that could be accessible to Ethiopia, mainly the Port of Djibouti (Tekeste, 1997).

The stated vision of Eritrea began to be frustrating when Ethiopia started to tighten its economic policies and to regulate the participation of resident and nonresident nationals from Eritrea, particularly in the sphere of banking, insurance, electricity, and power supply. Such new policies created resentment on the Eritrean part as it contradicted with their long-term strategy of making Eritrea an "African Singapore" (Gebru, 2006; Solomon, 1998). The Eritrean government began to show frustration as such policies were aimed at ousting Eritrea out of the Ethiopian economy and declared the new Ethiopian move a "protectionist policy" (Tekeste and Tronvoll, 2000: 44). Eritrea then called for the revision of the 1993 protocol to rectify the impasse and presented four demands: "free trade to ensure smooth transfer of Ethiopian products which could be re-exported, free movement of people, investment rights to Eritreans in Ethiopia on equal terms, and lastly make Nakfa a legal currency in Ethiopia on one-to one exchange with Birr." (Gebru and Awa'alom, 2005: 14-15) The deteriorated relation between the two states reached its climax when Eritrea launched Nakfa' ${ }^{1}$ as the national currency of Eritrea in November 1997. 
The introduction of Nakfa was believed to be the immediate cause of the war. Eritrea demanded the exchange rate between Nakfa and birr to be one-to-one and the two currencies would be freely serviceable in both countries (Gebru and Awa'alom, 2005). Ethiopia rejected Eritrea's claim for equal status between the birr and the Nakfa and it argued that "Nakfa did not have established a base within Eritrea and international trading system (Tekeste and Tronvoll, 2000: 35). Ethiopia also changed the old notes to the new currency in order to prevent the uncontrolled flow of old birr from Eritrea and also instituted cross-border trade control. Hence, all these changes created anxiety in Eritrea as they had brought an unexpected problem to their economy, and Eritrea criticized the Ethiopian policy as nothing but the "declaration of economic war" (Tekeste and Tronvoll, 2000: 37).

Bereket Haileslassie (2006) argued that the economic problem was a cover-up to the Ethiopian resentment of the "loss" of Eritrea. He further argued that the problem was basically related to the bureaucratic and technocratic monopolization of the Amhara; "the Amhara monopolized most of the key positions, including the sensitive posts in finance and banking, at the key sub-ministerial, technocratic level. Eritrean negotiators on the currency harmonization policy discussion complained that there was stiff resistance by these technocrats to the requests by the Eritreans to have a fair share in the currency" (Bereket, 2006: 26). Furthermore, Bereket contended that the problem with the currency was also related to the naming of the Eritrean currency after the Eritrean town, Nakfa that was a symbol of the armed resistance and triumph (Bereket, 2006: 27). Ethiopians, as the result, were determined to take revenge for their military defeat at Nakfa through economic warfare, and the Eritreans, too, considered Nakfa a symbol of achievement in economic development in particular and nation-building in general, which in turn resulted in "the Nakfa syndrome" (Gebru, 2009: 345).

\subsection{Securitized and militarized nation-building projects}

There is a common understanding that the basic sources of the conflict between the two states were related to "nation-building and governance structures" (Gebru, 2006: 58) adopted by the victorious nationalists in both countries, but inflamed by the evolving economic, currency, and border disagreements. According to Gebru (2006), the border dispute was a cover-up and the culmination of the deteriorated relationship between the two states. The border issue was only raised when agreements, mainly on economic issues, failed. As a result, the government of Eritrea pushed the issue of the border "to question the genuineness of Ethiopia's recognition of Eritrea an independent state as long as the border remained un-demarcated". Therefore, Gebru concluded that "the nature of the states and the historical process that created the Ethiopian and Eritrean states became important causes of the interstate conflicts." (Gebru, 2006: 57-59)

Following the downfall of the Dergue regime, the victorious nationalists were preoccupied with state-making and nation-building in Eritrea and state restructuring in Ethiopia. In Ethiopia, the EPRDF introduced an ethno-linguistic federal structure

\section{Hungarian Journal of African Studies (Afrika Tanulmányok)}


with the 1995 constitution that granted nations and nationalities the right to selfdetermination including the secession to address the historical question of nationality as stated in article 39. Eritrea, on the other hand, introduced a "unitary and centralized political system where ethnic or sub-regional identities have no place in the political space." (The Constitution of Eritrea, 1997) It was committed to neutralizing ethnicity, like in the case of post-colonial African states, in line with the principle of "one people, one heart" focusing on civic identity (Meressa, 2013), though it is a state of nine ethnic groups with two major contending religions (Islam and Christianity). Eritrea, therefore, opposed the Ethiopian ethnic federal system as it feared the possible spillover effects of ethnicity and the right to self - a determination that could ultimately negatively affect the Eritrean nation-building (Henze, 2001).

Nation-building in Eritrea was the continuation of war-induced mobilized nationalism as Eritrea has been a "war born state" (Bundegaard, 2004). The post-war civic national identity formation was rooted in "the invincibility of the Eritrean fighters and the great achievements of the EPLF during the armed struggle." (Bundegaard, 2004) The young and small state of Eritrea thus hoped to construct a single national identity that stands on the war-induced "homogeneity, unity and determination" (Gebru, 2006: 58) that negated the existential differences of Eritreans. However, there are also contending arguments that the 1998-200 war with Ethiopia was the latest manifestation of the strained and unholy relationship between the EPLF and the TPLF during their armed struggle (Ghidey, 1999). The relationship between the two parties was not based on "mutually balanced and reciprocal basis" but rather on a "senior-junior partnership" dominated by the EPLF's "superior, paternal and arrogant" attitude towards the TPLF (Ghidey, 1999: 3).

The parties also had major differences on the issues of military strategies, the nature of the Soviet Union, the question of nationalities, and united fronts. With regard to the question of nationalities, the TPLF had an opposite stance to the EPLF in recognizing the rights of nations and nationalities to self-determination and secession; however, the EPLF rejected them as disastrous sub-national entities. (Young, 1997) On the issues of military strategies, the TPLF also criticized the EPLF's professional, trench-based, and Sahel-confined strategy. Instead, the TPLF proposed a mobile peasant-based military strategy for both human and material sources (Gebru, 2005; Ghidey, 1999). The EPLF however opposed the TPLF military strategy on the ground that the latter actor was a junior partner in all issues including military doctrine and experience, and stated the TPLF stance as "an effort to present itself as experienced and knowledgeable, [...] in giving the EPLF a lecture as regards to military operation strategies" (Eritrean Ministry of Information, April 11, 2010).

Finally, given all the above differences between the two parties, the TPLF declared

Nation-building
in Eritrea was the
continuation of war-
induced mobilized
nationalism as Eritrea
has been a "war born
state".


that "the relationship with EPLF could be 'tactical' - based on nothing more than a shared commitment to eliminate their common enemy: the Dergue." (Ghidey, 1999) But strategically, the TPLF concluded that the EPLF was "a strategic enemy - an enemy that would ultimately prove to be deadly but which one cooperate[s] for a time being" (Gebru, 2005: 14-15). Therefore, post-war securitization and militarization were strongly framed and conditioned by the past relations of the two parties.

\subsection{A securitized and militarized border: Badme as a "casus belli"}

On May 12, 1998, Eritrea invaded Badme; the "casus belli" of the war. Many agreed, including the leaders of the two states, on an issue that the border was not the real cause of the war rather the culmination of the deteriorated relations between the two states.

The war, however, was fought for the reason that Gebru (2009: 344) put as "the contention between a new state too zealous to solidify its statehood and an older one too jealous to protect its sovereignty." The war also signified that the climax of Eritrea's aspiration to fully claim its military invincibility in the Horn of Africa through "standstill" (President Isaias, quoted in Bundegaard, 2004: 49) Ethiopia's regional hegemonic stance and redefining the regional power structure. Clapham (2000: 16) further added that the war initially helped Eritrea to "revive the memories of the 'struggle' and consolidate a sense of Eritrean nationalism that was in danger of being lost amidst the problems of peacetime administration" though he questioned the sustainability of the war-induced solidarity in peacetime.

Ethiopia, on its part, engaged in the war to defend its traditional reputation of repelling external aggression and reinstalling its regional power structure and balancer role that had been weakened by the more than two-decade-long civil war and its final cession of Eritrea in 1991 (Gebru, 2009). The war was also inflamed by strong rhetorical axioms of both countries' leaders to project their invincibility and power capability against their adversaries that in turn nullified diplomatic and peaceful endeavors. President Isaias stated that "withdrawing from Badme means the sun would never rise in the east for the second time." (Gebru, 2009: 345) On the Ethiopian part, General Samora Yenus denounced Eritrean trenches and fortifications not to be defensive against the Ethiopian army by stating that "the Eritreans are good at digging trenches and we are good at converting trenches into graves. They, too, know this; we know each other very well." (Gebru, 2009: 345) After nine months of preparation, Ethiopia declared "Operation Sun Set"- named after President Isaias's speech, on May 12, 1999. The war marked the military defeat of Eritrea and the end of its invincibility. The war continued up to 2000 and Ethiopia not only retook its contested areas but also deeply penetrated into the Eritrean territory; finally, Eritrea accepted the OAU peace plan.

\subsection{The Algiers Agreement and the EEBC Border verdict: securitization and militarization of the border}

On December 12, 2000, the Algiers ("December") Peace Agreement was signed between Ethiopia and Eritrea to resolve their border dispute by a neutral boundary 
commission. The agreement was concluded by the two countries after their acceptance of the OAU Framework Agreement and the modalities for its implementation, as well as the Agreement on the Cessation of Hostilities.

According to the signed agreement, the EEBC was given the mandate "to delimit and demarcate the colonial treaty border based on pertinent colonial treaties (1900, 1902, and 1908) and applicable international Law." (Art. 4.2: 3) As per the agreement, both parties agreed to "the delimitation and demarcation determinations of the commission to be final and binding" (Art. 4. 15: 6). Two years later, the EEBC announced its decision regarding border delimitation. Ethiopia, via Foreign Minister Seyoum Mesfine, declared that it had won all its claimed territories including the contested territories such as Badme and its surroundings, and viewed the decision "just and fair" that makes Ethiopia victorious in both "military and legal battles" (Seyoum, 2002: 13).

Ethiopia anticipated that "after the reversal of the Eritrean aggression and maintenance of the status quo ante, the commission would easily ensure its legal sovereignty over the contested areas as it had administered them for decades." Indeed, "Ethiopia from the very beginning viewed both the Algiers Agreement and the EEBC, as essentially legal instruments to smooth over the results of the war and to bring lasting solution without challenging its right to hold territory that it had administered in modern times." (Clapham, quoted in Medhane, 2004: 81) The Ethiopian government could not have imagined that the commission would transfer the contested territories to Eritrea, if so, it would be nothing but rewarding an aggressor (Medhane, 2004).

However, after a year, the commission came up with the clarification of its ambiguities and said that Badme lied within the Eritrean claim line. The Ethiopian government expressed its regret and declared that it would not accept the ruling specifically over the awarding of Badme to Eritrea that it had historically been administered by Ethiopia. Ethiopia expressed its unhappiness over the ruling of the EEBC, especially over "the legality and fairness of the ruling, the integrity of judges and deviations from the spirit of the Algiers Agreement i.e. ensuring long-lasting peace" and it moved to outright rejection of the commission's allocation of key areas as "unfair, unbalanced, unworkable and impossible to implement." (Medhane, 2004: 82)

In a letter written to the UN Security Council in September 2003, Prime Minister Meles condemned the commission's decision as "unjust" and "illegal" that violated the main objectives of the Algiers Agreement, i.e. ensuring lasting peace and stability in the region. He expressed the difficulties that Ethiopia had to face to accept the decision, specifically in symbolic areas as:

It was unimaginable for the Ethiopian people to accept "a blatant miscarriage of justice" - specifically over the awarding of Badme to Eritrea. Badme was symbolically important and the casus belli for the two years' war. The decision is thus a recipe for continued instability, and even recurring wars... nothing worthwhile can, therefore, be expected from the commission to sal- 
vage the peace process ...indeed, the commission seems to be determined to continue its disastrous stance whatever the consequence to peace in the region (Meles, 2003:10-11).

Ethiopia's request to the EEBC and the UNSC to rectify the problem through "correction and interpretation" (Medhane, 2004: 82) failed to be accepted. The decision of the commission, however, began to challenge the post-Algiers power balance. Ethiopia was militarily victorious but the new status quo did not support territorial change. Eritrea, on the other hand, was legally victorious but did not have the military power to implement the decision unilaterally and overturn the post-Algiers regime along the disputed areas, which made the decision unworkable (Medhane, 2004: 82). Ethiopia criticized the EEBC for apparently confirming Eritrean sovereignty over Badme, failing to blame Eritrea for the aggression and to develop a long-term solution, and for the incapacity of the commission to rectify the anomalies on the basis that its decision is final and binding. As a result, the "no war, no peace' régime began to govern the relationship between the two states, and on May 12, 2018, both states remembered the "20 years of no war, no peace anniversary".

On November 25, 2004, Prime Minister Meles submitted a new five-point peace initiative entitled "Report on the New Ethiopia Eritrean Peace Initiative" to the House of Peoples' Representatives. In the peace initiative, he underlined that the decision was unjust and illegal (Medhane, 2004: 6-7).

The first point of the initiative was a call to peacefully resolve the problem through dialogue and negotiation based on the principle of give and take." (Meles, 2004: 11) It nullified force as a means of resolving disputes and ensuring durable and sustainable peace. Cognizant of the first point, the second point called for addressing "the root cause of the conflict with a view to normalize relations between the two countries and peoples." (Meles, 2004: 12). The third point "accepts the verdict, in principle" (Meles, 2004: 14), which was the major turnaround for the Ethiopian government which had once described the decision as "unacceptable" and which it still called "illegal and unjust". Accordingly, Ethiopia, in principle, made a step forward from the earlier blanket rejection of the decision to acceptance in broad terms without going into specific details that could be hoped to be the basis for dialogue and to help the commission continue its work including the work of demarcation while discussing implementation. The third point was expected to be a response to the Eritrean accusation of Ethiopia for its unwillingness to accept the decision as well as for the international community that viewed Ethiopia as an obstacle to the realization of the decision. Lastly, the initiative called for "dialogue on implementation of the EEBC's decision in a manner consistent with the promotion of sustainable peace and brotherly ties between the two peoples." In this point, however, the prime minister warned that "... an attempt to implement the decision of the Commission, as is, might lead to a serious escalation of tension between the two countries and thereby undermine the peace process." (Meles, 2004: 17) 
Eritrea, once it was assured that Badme was within its claim line, called for the immediate implementation of the decision without any precondition. It strongly declared that "any notion of dialogue regarding the border issue with Ethiopia is closed and hermetically sealed." The commission made it "crystal clear that the case was put to rest once and for all...final means binding there is not dialogue to be carried out on the issue." (Ogbazgy, 2006: 2)

With regard to the five-point peace proposal, Eritrea's position has been the same, i.e., nothing but the full implementation of the decision. It clearly opposed the initiative that "if there will be any dialogue it should only [come] after the demarcation of the whole border is completed and Eritrea gains full sovereignty over its territories. Ethiopia's attempt to make an association and comparison with the border dispute of Nigeria and Cameroon is an obscured comparison." (Ogbazgy, 2006: 2) Therefore, it viewed the proposal as nothing but brinkmanship in order not to implement the rulings of the EEBC immediately.

At the core of the stalemate is that ceding the symbolic areas would have grave implications for the domestic security and regime legitimacy of both states as the war was fought in the name of those symbolic areas. After all, negotiating and ceding symbolic areas would be considered as a capitulation to their adversaries who both claimed victory. Eritrea stated its withdrawal from the contested areas as a strategic retreat, locally known as 'Mizlak' (Healy, 2008). On the Ethiopian part, the war was fought to defend its territorial integrity from external aggression. After the war, Ethiopia has emerged as a militarily stronger actor compared with its neighbors who could deter military aggression, and as a result, it has reinstalled its traditional regional hegemonic leadership. Hence, it would be improbable, given Eritrea's internally emerging security problems and nation-building failures, its isolation from the international community (the UNSC sanctions of 2009 and 2012), and more importantly its inability to challenge Ethiopia's diplomatic and military muscle, to surrender the symbolic areas to the existing Isaias regime, in which both governments frequently stated that the root cause of the conflict was not the border itself. 


\subsection{The 'no war, no peace' regime: Refugee crisis and indefinite deadlock}

Eritrea's stubbornness to firmly stick to the ruling, having the law on its side, and its failure to get the sympathy of the international community to pressure Ethiopia to comply with the EEBC decision (the handover of Badme), indicated its inability to challenge Ethiopia's diplomatic and military deterrence power. Its failure to challenge the diplomatic muscle of Ethiopia, in the eyes of the great powers, mainly America, also made Eritrea turn back to its traditional policy of isolationism ("the North Korea syndrome') under the principle of "self-reliance", viewing the American-led world as full of injustice.

Following the EEBC verdict and Ethiopia's failure to implement it, the Eritrean national security threat became clear and visible. As a result, the Eritrean government indefinitely declared a state of emergency for the fear of the existential threat, mainly of regime change and re-colonization, posed by Ethiopia. The Eritrean government continued to tighten its control to sustain the controlled nation-building by declaring a state of emergency to deter Ethiopia and its ally's potential threat to its sovereignty though it had never sent a notification to the United Nations Secretary-General (UN Human Rights Council, 2016: 19). Moreover, the war dashed the hopes of political inclusion, reconciliation, and the system of multiparty politics was also challenged when the government declared national security a paramount priority. Dan Connell (2005:2) characterized the postwar trajectory of Eritrea as similar to the "crisis of the postcolonial African state and the corruption of the political process" defined by the concentration of power in the hands of President Isaias, the closure of the parliament, the establishment of a special court to undermine the judiciary to imprison the enemies of the regime or send journalists and vocal critics including G- $15^{3}$ to exile, and the closure of independent media accused of being "foreign-funded" and "engaging in defamation and rumor-mongering" (UN Human Rights Council, 2016: 35). According to the Freedom House Report of 2016, Eritrea still falls under the category of the 'Worst of the Worst' list of 11 countries as it scored 3 out of 100, while the next country, Syria has a rating of "-1" regarding the situation of the violations of political rights and civil liberties.

The Commission of Inquiry on Human Rights in Eritrea also declared that the Eritrean government had engaged in a "systematic and widespread" violation of rights. Furthermore, it stated that the abuses had been occurring "in the context of absences of rule of law", that is why the commission affirmed in the final analysis that "it is not the law that rules Eritreans but fear." (UN Human Rights Council, 2016: 46) Many of the critical young generation are in the military trenches indefinitely as part of the national service, which is the basic reason for thousands to leave the country with no possibility to return in the foreseeable future. As a result of such policy, only underage and over-age people remain in Eritrea, and for this reason, Yosief Gebrehiwot, the Eritrean well-known activist, defined the situation as "generational genocide" (2017: 12), though president Isaias Afeworki repeatedly stated that the continuing migration of Eritreans had been an externally induced political 
conspiracy of the Western states to undermine Eritrea's human resource base and "self-reliance" based on nation-building.

Matina Stevis and Joe Parkinson summarized the refuge crisis in the Wall Street Journal (2016: 2) by calling Eritrea "one of the world's fast emptying nations [...] plays an outsize role in the biggest global migration crisis since World War II." Furthermore, they added that "attention is focused on [...] Syrians, [...] yet by some measures, the exodus from the smaller Eritrea is more extreme. From the start of 2012 [...], one in fifty Eritreans sought asylum in Europe, nearly twice the ratio of Syrians." (Stevis and Parkinson, 2016: 2) Eritrea is often referred to as the "North Korea of Africa' as the military regime is isolated and totalitarian, and also mentioned as a "second Somalia" for the reason that the state and the regime functionally "failed" and the descent of the country into civil war in the hotbed region of the Horn of Africa is imminent.

On the Ethiopian side, the Ethiopian government redefined its pre-1998 good neighborhood policy towards Eritrea and re-institutionalized the policy of building a modern army to "deter, isolate and defeat" (Ethiopia's Foreign and National Security Policy, 2002) incoming national security threats not only from Eritrea but also from other neighboring states. The Ethiopian government, under a developmental democratic state ideology (DDS) and "renaissance vision", defined poverty as an existential threat to Ethiopia's territorial integrity and security as it creates an enabling conductions for the resurrection of chauvinism, narrow-nationalism, and Islamic fundamentalism (EPRDF, 2005).

By the containment policy, the Ethiopian government relegated the threats emerging from Eritrea to a secondary status which requires "passive deterrence" and counterinsurgency policy against Ethiopian insurgent forces hosted by the Eritrean government (Meles, 2010). The 'containment policy', therefore, imposed the 'no war, no peace' regime on Eritrea to deter and isolate with ultimate goal of regime change by the Eritrean forces of change (Yosief, 2017). It was basically focused on "proportional measures" for every provocation by the Eritrean government.

The 'containment policy' of the Ethiopian government against Eritrea was successful in deterring military aggression and isolated Eritrea diplomatically from the international and regional community. However, Eritrea is still a potential threat to Ethiopia's national security for the reason that the border has still remained undemarcated, no investment and development have been realized in the conflict areas, six refugee camps were established in the war zone due to the Eritrean refugee crisis, furthermore, Eritrea leases ports to competing Arab countries (like Qatar, Saudi Arabia, Iran, and the UAE) scrambling for the Horn of Africa's coastal zone to let them use as a military base in their fight against Yemen. The Arab countries' struggle for the coastline and the militarization of the Red Sea and the Bab-el-Mandeb triangle have further isolated the landlocked state of Ethiopia and have militarized Eritrea with no prospect for normalization and reconciliation between the two states as the Arab countries have been hostile to Ethiopia's national security interests since the 1960s. The problem of the failed state of Eritrea has been becoming an existential 
threat to northern Ethiopia given terrorism is becoming pervasive in the Middle East and around the Red Sea which all ultimately make Ethiopia surrounded by failed states.

\section{A 'fragile rapprochement': post-July 2018 phenomenon}

After 20 years of "no war, no peace" stalemate (1998-2018) between Ethiopia and Eritrea, in March 2018 the EPRDF (Ethiopia's ruling party since 1991) elected Abiy Ahmed as a new party chairman and consequently the prime minister of Ethiopia. Prime Minister Abiy Ahmed, in his inaugural speech in April 2018 made a call for normalization and to end the "no war, no peace" stalemate.

Unlike the 20 years of stubborn and antagonistic policy towards the EPRDF government in Ethiopia, on June 20, 2018, on the Eritrean Martyr's day held in $\mathrm{Sawa}^{5}$, president Isaias Afeworki accepted the call for rapprochement and declared that he would sent his delegation team to Addis Ababa "to gauge current developments directly and in depth as well as to chart out a plan for continuous future action" (Eritrean Ministry of Information, 20 June 2018) with Abiy Ahmed's EPRDF leadership. Moreover, President Isaias proclaimed that he accepted the call for normalization from Abiy Ahmed and his new EPRDF leadership (also known as "Oro-Mara EPRDF" $)$ as the era of TPLF dominated EPRDF has gone following the protracted protests since 2015. He further stated that the Ethiopian people said "enough is enough" and he famously described the change in EPRDF leadership as "Game Over" with the TPLF dominated EPRDF era (Jonathan and Meressa, 2018:195). He underlined that the 20years hostile relationships between Ethiopia and Eritrea was because of the misguided policies of the TPLF-EPRDF government supposedly supported by the pre-Trump American administration.

On the morning of July 8, 2018 Abiy Ahmed made a landmark visit to Asmara, the first seating prime minster to visit Eritrea after the 1998 war. The people of Asmara poured into the street to receive the Ethiopian delegate led by Prime Minister Abiy chanting slogans like "Selam at last" (Tigrigna for peace at last), "love wins", "yes peace, no war", and "game over"(Billion, 2018:13-14).

On July 9, 2018 the leaders signed a "joint Declaration of Peace and Friendship" (Addis Standard, 2018) that consists of seven articles. Article-one of the agreement stated that "the state of war between the two countries has ended and a new era of peace, friendship and comprehensive cooperation has started". The two states also agreed to "promote comprehensive cooperation in the political, security, defense, economic, trade, investment, cultural and social fields on the basis of complementarities and synergy" (Ibid). More fundamentally, the two leaders reaffirmed their commitment to "implement the Eritrea-Ethiopia Boundary Commission decision" that has been remained as the structure problem for a war torn and "no war, no peace" deadlock (Ibid).

On July 9, 2018, the UN Secretary General Antonio Guterres visited Addis Ababa following the signing of the joint declaration of peace and friendship in Asmara and he promised that the UN sanctions on Eritrea would be lifted. He further elaborated 
that "the sanctions were motivated by a number of events that took place, (but) it is my belief that those events will no longer exist...If the reasons that led to the sanctions will no longer exist...they will naturally become obsolete"(Fikreyesus, 2018:22). Mike Pompeo, US Secretary of State, also praised that deal between Ethiopia and Eritrea in such a way that "peace between Ethiopia and Eritrea will further the cause of stability, security, and development in the Horn of Africa and Red Sea" (July 10,2018). Finally, on December 14, 2018, the UN Security Council unanimously lifted the nine years old sanctions (army embargo, assets freeze and travel ban) on Eritrea which were imposed on claims that Eritrea supported al-Shebab militants in Somalia (BBC, December 14, 2018).

The hope for normalization was further strengthened when President Isaias Afeworki visited Addis Ababa on July 14, 2018 for the first time since 1998 and warmly received by the people of Addis Ababa. On his address to the Ethiopians from the national palace in Addis Ababa president Isaias stated that "from now onwards anyone who thinks that Ethiopia and Eritrea are two different countries is the one who fails to know the truth" (ERi-TV, July 14,2018). Such remarks of the president in Addis Ababa later resulted in a shock on the Eritrean side fearing that he will sell-out Eritrea sovereignty and independence to Ethiopia as in the case of 1952 federal arrangement. Finally on July 16, 2018 he reopened the Eritrean Embassy in Addis Ababa in order to officially started diplomatic relations. As a result of the Rapprochement President Isaias And prime Minister Abiy received the United Arab Emirate Crown Prince's highest medal award ("The Zeyed Award") in July 24, 2018 and Saudi Arabia's highest medal ("the Order of King Abdul-Aziz") in September16, 2018 (Tesfa News,2018).

Even though, the breakthrough rapprochement between the two leaders sparked a new hope for sustainable peace, the prospects for normalization and reconciliation still remain elusive. The details of the agreements are still remaining secret and known only to Prime Minister Abiy and President Isaias and their sponsors like the Kingdom of Saudi Arabia and UAE though citizens of both countries have been asking the disclosure of details of the agreements and get approved by relevant institutions like national parliaments, regional organizations (AU and IGAD) and International Organizations (like the UN). Moreover the rapprochement fails to address the fundamental causes of the two decades conflict including border demarcation, disarmament and demobilization, currency and custom harmonization, port politics and issues of Eritrean refugee resettlement. And a result, refuge crisis is continuing as defining agenda of the future relations between Ethiopia and Eritrea.

\section{Even though, the breakthrough rapprochement between the two leaders sparked a new hope for sustainable peace, the prospects for normalization and reconciliation still remain elusive.}


Furthermore, both leaders also failed to ensure peace, security and democratization in their respective states after the rapprochement. President Isaias failed to reform his totalitarian government, end the indefinite national conscription, release political prisoners and decriminalize political forces struggling for freedom and democracy as in the case of Abiy Ahmed reforms. The Eritrean become more worried about the prospects for normalization as there are no signs of reform under Isaias Afeworki and even they fear that President Isaias would compromise Eritrea's sovereignty and territorial integrity in favor of regional integration of the Horn or con-federal arrangement with Ethiopia. And hence, they continue their struggle, under the resistance theme of "Yiakel" to dictator and yes for rule of law" (ATV, April 14, 2019) against totalitarian leadership of president Issais and secret agreement with Prime Minister Abiy.

On the Ethiopian side, protracted ethnic and social conflicts have become pervasive, even after it normalized its relation with Eritrea, and Ethiopia is recently branded as "failed state" characterized by "lack of control over armed forces, militias, lack of free participation in politics, lack of control over territory within national borders, Massive displacements, failure to provide public services food, health, shelter etc, high level of corruption, high numbers of refugees seeking to leave , and no or poorly functioning economy" (Dawit, 2019: 2-3). As a result, the hope for sustainable normalization and reconciliation increasingly become fragile and volatile. Surprisingly, the Eritrean government unilaterally closed the Zalaambesa (central part) border crossing on December 28, 2018. The western (Omhajer- Humera) and eastern (Bure-Assab) parties of the Ethiopia Eritrea border crossings were finally closed on April 18 and 23, 2019 respectively. As a result it shocked Eritrean and Ethiopian people and hence a threat of regional conflict is looming which in turn, if interstate conflict again erupts, transforms the region into new wave of re-militarization and protracted regional conflict.

\section{Conclusion}

The Ethiopia-Eritrea war ended Eritrea's military invincibility and weakened its leadership's vision of power projection instigating instability against its neighbors. Economically, the war also ended Eritrea's vision of 'Singaporization' to become the "industrial houses of the Horn of Africa". The port-based (Massawa and Assab) national economy has lost its comparative and competitive advantage to Djibouti for the decades to come, and the policy of "self-reliance" has proved to be a structural failure of a poor war-torn state in the era of globalization. The Eritrean ports have been leased as a military base to regionally competing Middle Eastern countries, previously to Shia Iran and Qatar, and after the Yemen crisis, since 2013, the management of some Eritrean ports have been transferred to Saudi Arabia and the UAE. Due to the proxy wars and the regional hegemonic competition between Shia and Sunni Arab counties, Eritrean ports are getting militarized. Eritrea is also called the 'North Korea of Africa', a functionally "failed" state, and on the verge of 'Somalization'. 
Following the protracted protests in Oromia and Amhara regional states since December 2015, in April 2018 a new 'Oro-Mara' leadership emerged within the EPRDF under Prime Minister Abiy Ahmed. Abiy Ahmed is the first Oromo leader in modern history of Ethiopia. After he took office, he made a call for normalization of the 20 years "no war, no peace" stalemate and surprisingly he well received by president Isaias and the Eritrean people. The new rapprochement policy was equally praised by international institutions and superpowers. It was celebrated that it would transform the two decades stalemate, militarization, securitization and refugee crisis between Ethiopia and Eritrea and contributes to the peace and security of the conflict prone Horn of Africa. The prospects for normalization and reconciliation, however, remain fragile and un-institutionalized as the agreements continue to be 'secret, externally induced and failed to address the root causes of the stalemate'. After eight months of open border relationship between the states, the Ethiopia Eritrea borders again closed in April 2019. Militarization and securitization of relations thus become a structural dilemma with bigger repercussion to the security of Horn of Africa and Red Sea.

\section{Notes}

1 Nakfa was the military and political base of the EPLF during the armed struggle. It is known in the history of Eritrean liberation struggle as symbol of resistance, heroism, and determination of the Eritrean guerrilla fighters in their struggle against the Dergue regime of Ethiopia. It was the stronghold of the EPLF where they defeated the Dergue's all-inclusive military campaign known as 'the red star campaign' in cooperation with the TPLF. Thus, the Eritrean national currency was named after the place Nakfa.

2 Eritrea-Ethiopia Boundary Commission

3 EPLF/PFDJ Central Committee and Politburo members who were imprisoned by President Isaias allegedly for committing crime of "subnationalism" and "defeatism" in September 18, 2001.

4 The late Prime Minister Meles Zenawi on September 1, 2000, declared to build a "new Ethiopianism" through a renaissance project for socioeconomic transformation, where the rights of nations and nationalities to self-rule are ensured, and consensus-based national unity (federalized Ethiopianism) is achieved. He claimed that "the third Ethiopian millennium would be as good as the first millennium and not as bad as the second millennium." The first millennium was marked by the Axumite civilization, when Ethiopia enjoyed the most prosperous period in its history, but the second millennium was remembered as an era of political-economic decline, protracted civil wars, famine (e.g., in 1985), crisis of national unity, etc.

5 Also known as "Warsay-Yikaalo School". Warsay refers to the post-independence Eritrean generation and Yikaalo is the liberation struggle generation. Warsay is Tigrigna for "heir" and Yikaalo is Tigrigna for "able"- a generation who able to realize the independence of Eritrea from Ethiopia. Thus Warsay- Yikaalo school is the political and military training center to integrate the two generations and ultimately support the new nation building project of the new state of Eritrea under the theme of "one people, one hear" and "United we stand".

6 A new coalition of Oromo People Democratic Organization (OPDO) and Amhara Nation Democratic movement (ANDM) emerged within the EPRDF following the protests since December 2015 in Oromia and Amhara regions. It was to challenge the post1989 EPRDF establishment that was dominated by the TPLF. It is an alliance of the two largest ethnic (Oromo and Amhara) groups to counter the TPLF (Tigriyan) ethnic groups in Ethiopia. The 
new Abiy Ahmed EPRDF Leadership is also popularly known as "Oromara-EPRDF" that replaced "TPLF-EPRDF" era in post-1991 Ethiopia.

7 Tigrigna for "Enough"

\section{Bibliography}

- Addis Standard. (2018). Agreement on Peace, Friendship and Comprehensive Cooperation between the Federal Democratic Republic of Ethiopia and the State of Eritrea available at http://addisstandard.com/full-text-of-the-ethio-eritrea-agreement-signed-in-jeddah/

- ATV. (April 14, 2019). "Enough--Cuct-Message to All Eritrean -We Stand With My Peoplepart 3" available at https://www.youtube.com/watch?v=Ds-LkG4UoSk\&t=4s

- Awa'alom, W. and Gebru, A. (2005). TPLF, EPLF and why peace eludes them. The Reporter 9 (449), 14-15.

- BBC. (December 14, 2018). "Eritrea Breakthrough as UN sanctions Lifted" available at www. bbc.com/news/amp/world-africa-46193273

- Bereket, H. (2006). Dreams that Turned to Nightmares: The Ethio-Eritrean War of 1998-2000, and Its Aftermath. In: Leta, L. (Ed.). The Search for Peace: The Conflict between Ethiopia and Eritrea (PP25-30). Proceedings of Scholarly Conference on the Conflict of Ethiopia and Eritrea, July 6-7, 2006, Oslo.

- Berhane, W. (2006). Eritrea: the War for National Unity. In: Leta, L. (Ed.). The Search for Peace: The Conflict between Ethiopia and Eritrea (PP31-40). Proceedings of Scholarly Conference on the Conflict of Ethiopia and Eritrea, July 6-7, 2006, Oslo.

- Billion, T. (2018). Selam at last! Eritrea and Ethiopia join in peace after two decades of Hostilities. Eritrea Profile 25 (38), 13-21.

- Bundegaard, C. (2004). The Battalion State: Securitization and Nation-Building in Eritrea. Programme for Strategic and International Security Studies, Geneva.

- Buzan, B. (1991). People, States and Fear: An Agenda for International Security Studies in the Post-Cold War Era. Harvester Wheatsheaf, New York.

- Clapham, C. (2000). War and State Formation in Ethiopia and Eritrea. Paper presented at the colloquium: La Guerre entrerele local et le global, Centre d'Etudes et de Recherches Internationales, May29-30, Paris.

- Connell, D. (2005). Conversation with Eritrean Political Prisoners. The Red Sea Press Inc., Trenton.

- Dawit, W.(2019). "Ethiopia: A Country on the Brinks" available at https://borkena.com/2019/04/10/ ethiopia-a-country-on-the-brinks-by-dawit-woldegiorgis/

- EPRDF. (2005). Revolutionary Democracy and Ethiopian Renaissance, EPRDF ideology. Mega Printing Press, Addis Ababa.

- Eritrean Ministry of Information (2018). Eritrea: 'President Isaias' speech on Martyrs' Day', 20 June 2018 available at http://www.shabait.com/news/local-news/26520-president-isaiasspeech-on-martyrs-day

- Eritrean Ministry of Information. (2010). "Ethiopia: At a Decisive Stage between Its People and the TPLF (Part III)" available at http://www.shabait.com/categoryblog/1555-ethiopia-ata-decisive-stage-between-its-people-and-the-tplf-part-iii

- ERi-TV. (July 14, 2018). "ERi-TV, Eritrea: Ethiopia Welcomes President Isaias Afwerki, July 14, 2018 - Part III" available at https://www.youtube.com/watch?v=ExTYKWrVAn0

- Fikreyesus, A. (2018). Eritrea and Ethiopia: Recap and Brief Commentary on Recent Developments. Eritrea Profile 25 (39),

- Freedom House. (2016). Anxious Dictators, Wavering Democracies: Global Freedom under Pressure. Freedom House available at https://freedomhouse.org/report/freedom-world/freedom-world-2016 
- Gebru, A. (2006). Towards a Sustainable Peace between Ethiopia and Eritrea. In: Leta, L. (Ed.). The Search for Peace: The Conflict between Ethiopia and Eritrea (PP53-62). Proceedings of Scholarly Conference on the Conflict of Ethiopia and Eritrea, July 6-7, 2006, Oslo.

- Gebru, T. (2009). The Ethiopian Revolution: Wars in the Horn of Africa. Ohio University Press, Athens $\mathrm{OH}$.

- Ghidey, Z. (1999). The Ideological and Political Causes of the Ethio-Eritrean War: An Insider's View. Paper for the International Conference on the Ethio-Eritrean Crises, July 24, 1999, Amsterdam.

- Healy, S. (2008). Eritrea's Regional Role and Foreign Policy: Past, Present and Future Perspectives. London: Royal Institute of International Affairs.

- Henze, P. (1985). Rebels and Separatists in Ethiopia: Regional Resistance to a Marxist Regime. Santa Monica: Rand.

- Hough, P. (2004). Understanding Global Security. Routledge, New York.

- Jonathan, F. and Meressa T. (2018). 'Game over'? Abiy Ahmed, Tigrean People's Liberation Front and Ethiopia's political crisis. African Affair 118(470), 194-206.

- Klare, M. (1978). Militarism: the issues today. Bulletin of Peace Proposal 9 (2)

- McDonald, M. (2008). Securitization and the construction of security. European Journal of International Relations 14 (4), 563-87.

- Medhane, T. (2004). Turning Conflicts to Cooperation: An Energy-led Integration in the Horn of Africa. Frederic Ebert Stiftung, Addis Ababa.

- Meles, Z. (2010). Counterinsurgency: strategies, tactics and doctrines. Addis Ababa.

- Meles, Z. (2004). Report on the New Ethio-Eritrea Peace Initiative Submitted to the House of Peoples Representative. House of Peoples Representative, Addis Ababa.

- Meles, Z. (2003). Correct Errors when shown to be errors. The African Economist 7 (19), $10-11$

- Meressa, T. (2013). Nation-building challenges in post-independent state of Eritrea and its regional domino effects. Journal for the Study of Peace and Conflict, 21-36.

- Ogbazgy, A. (2003). Demarcation Is the Only Option for Peace in the Border Dispute Between Ethiopia and Eritrea available at http://dehai.org/demarcation-watch/articles/Ogbazgy_ Abbay_Asmerom_demarcation_is_only_option_for_peace.html [02.02.2019]

- Pompeo, M. (2018). Eritrea and Ethiopia End War and Adopt Joint Declaration of Peace and Friendship available at https:/www.state.gov/secretary/remarks/2018/07/283930.htm

- Rourke, J. T. (1993). International politics at the world stage (4 ${ }^{\text {th }}$ Ed.). The Dushkin Publishing Group, Inc., Connecticut.

- Seyoum, M. (2002). Ethiopia Victorious Again. The African Economist 2 (4), 13.

- Solomon,I. (1999).Key Determinants of Ethiopia-Eritrea Crises. In Walta Information Center (Ed.), Dispatches from the Electronic Front (PP6-20). Addis Ababa: Berhanena Selam Printers.

- Stevis, M. and Parkinson, J. (2016). African dictatorship fuels migrant crisis: Thousands flee isolated Eritrea to escape life of conscription and poverty, The Wall Street Journal available at https://www.wsj.com/articles/eritreans-flee-conscription-and-poverty-adding-to-the-migrant-crisis-in-europe-1445391364 [02.02.2019]

- Tesfa News. (September 16, 2018). "Leaders of Eritrea and Ethiopia received Saudi Arabia's Highest Honour" available at https://www.tesfanews.net/eritrea-ethiopia-leaders-receivedsaudi-arabia-highest-award/

- Tanter, R. (1984). Trends in Asia. Alternatives (Special Issue on Militarization) 10 (1).

- Taureck, R. (2006). Securitization theory and securitization studies. Journal of International Relations and Development 9, 53-61.

- Tekeste, N. (1997). Eritrea and Ethiopia: The Federal Experience. New Brunswick: Transaction Publisher. 
- Tekeste, N. and Tronvoll, K. (2000). Brothers at War: Making Sense of the Eritrean Ethiopian War. Ohio University Press, Athens OH.

- Tronvoll, K. (2009). The Lasting Struggle for Freedom in Eritrean: Human Rights and Political Development, 1991-2009. Oslo: HBO AS.

- UN Human Rights Council. (2016). Report of the Commission of Inquiry on Human Rights in Eritrea available at http://www.ohchr.org/Documents/HRBodies/HRCouncil/CoIEritrea/A HRC 32 CRP.1 read only.pdf [02.02.2019]

- Wæver, O. (2007). Securitization and desecuritization. In: Buzan, B. and Hansen, L. (Eds.). International Security: Widening Security. SAGE Publications, London.

- Walt, S. M. (1991). The Renaissance of Security Studies. International Studies Quarterly 35, 212-239.

- Willans, S. (2004). Human Security and the Evolution of Security: Case Study - Northern Uganda Conflict. PhD. Dissertation, Dalhousie University, Halifax.

- Wing, I. (2000). Refocusing Concepts of Security: The Convergence of Military and NonMilitary Tasks. Land Warfare Studies Centre Working Papers 111.

- Yemane, G. (July 8, 2018). Ethiopia's PM Abiy Ahmed in Eritrea for landmark visit available at https://www.aljazeera.com/news/2018/07/ethiopia-pm-abiy-ahmed-eritrea-landmark-visit 180708083000438.html

- Yosief, G. (2017). Ethiopia and Eritrea: The Waiting Game. Discourse 1 (1), 4-15.

- Young, J. (1997). Peasant Revolution in Ethiopia: Tigray Peoples Liberation Front, 19751991. Cambridge University Press, Cambridge.

\section{Documents}

- Algiers Agreement of Ethiopia and Eritrea. (2000). December 12, 2000, Algiers

- Agreement on Cessation of Hostilities. (2000). June 18, 2000, Algiers

- Elamanan, N. (1971). Our Struggle and Its Goals. Eritrean People's Liberation Front Manifesto.

- Ethiopia - Eritrea Boundary Commission/EEBC/Delimitation Decision. (2002). April 13, 2002

- Ethiopia's Foreign and National Security Policy. (2002)

- The Ethiopian Federal Democratic Republic Constitution of 1995. (1995)

- The Constitution of Eritrea (not implemented). (1997).

- The Proclamation of National Service of the State of Eritrea, Proclamation No. 82/1995. (1995). 